\title{
The Influence of Tianjin College Entrance Examination Reform on Teaching Progress, Quality and Effect
}

\author{
Feng Xiangyuan \\ Yaohua High School, fengxiangyuan65@126.com
}

\begin{abstract}
Keywords: English college entrance examination; teaching progress, teaching quality, teaching effectiveness

Abstract. The reform of college entrance examination has a great influence on teaching progress, quality and effect. Therefore, based on the above background, this paper takes the reform committee of English college entrance examination as the main object, and carries out the following research: The first part is the analysis of the college entrance examination reform. The second part is the Multiple regression analysis of the impact of the English college entrance examination on teaching quality and content in Tianjin. The third part is the strategy of making the positive effect of the college entrance examination on English teaching in senior high school. This article would point out the direction for the Tianjin English college entrance examination.
\end{abstract}

\section{The Analysis of the English College Examination Reform}

College entrance examination, as a national examination, is the most important exams in China. The reform orientation of college entrance examination directly affects the orientation of the school teaching and students' learning subjects. Since the time that the country resumed the college entrance examination system, Chinese, mathematics and foreign language become the most important three subjects in the college entrance examination in. Since then, Chinese students have allocated more time to English than many other countries.

Reasons for English College Examination Reform. The beginning of English reform is bound to affect the way the entire exam-oriented education, if there is a discipline can receive the reform, then the discipline must be English. English teaching has its own shortcomings, in order to adapt to the pace of the times, the English reform as a breakthrough, is to open the door to reform a key.Most of the current students learn what the examination requires, we can analyze the contents of the examination of the candidates English ability: a certain amount of words, can read the English article, the ability to write in English, be able to apply grammar tenses.

Purpose of English College Examination Reform. Today's society has a low level of awareness and understanding of English and its test, while the information passed to students through exam-oriented education also distorts the focus of learning the language. In fact, the purpose of learning any language, are trying to inherit the nation's culture, science and technology, thinking and so on any of our lack of knowledge to learn and access, so that our own progress. Guide learning direction.

\section{A Multivariate Analysis of the Influence of Tianjin College Entrance Examination Reform on Teaching Progress, Quality and Effect}

Research Target. In order to ensure the reliability of the survey data, we use the original data of 2016 students' evaluation of teaching in Tianjin University. The teaching quality evaluation table of college English teachers involved in teaching evaluation includes 20 factors - teaching attitude, teaching content, teaching method, teaching organization, teaching effect and so on. In Table 1, the evaluation results of each factor are divided into 5 grades, namely very poor, poor, general, good, pretty good, respectively, represented by 1, 2, 3, 4 and 5 points. According to the scores of students' effective evaluation of English teachers' teaching quality, the average scores of 20 English teachers were calculated and the database of English teachers' teaching quality was established. The database 
contains a score of 2060 evaluations of 203 English teachers (expressed as x1-x20, respectively) for a total of 4,060 observations.

Research Method. We introduce the dummy variables, use the above-mentioned student evaluation database, establish the linear regression model and the use the SPSS1211 statistical software to analyze the parameters of the regression model, so as to explore how English teachers 'teaching attitude, teaching content, teaching method and teaching organization influence the English teachers' teaching effect and to find out the main factors affecting the quality of teaching.

Table 1. Evaluation Factors of Teaching Quality of College English Teachers

\begin{tabular}{|c|c|}
\hline \multicolumn{2}{|c|}{ Description of variables } \\
\hline $\mathrm{X} 1$ & Adhere to school discipline, on time to get out of class \\
\hline $\mathrm{X} 2$ & Be enthusiastic about their teaching work and full of class spirit \\
\hline $\mathrm{X} 3$ & Respect the views of students, can be taught in accordance with their aptitude \\
\hline $\mathrm{X} 4$ & Words and deeds would help students to study and be a man \\
\hline $\mathrm{X} 5$ & Be familiar with the teaching content, use freely \\
\hline X6 & Update the teaching content, reflecting the forefront of the subject and the latest results \\
\hline $\mathrm{X} 7$ & Recommended reference books are good for teaching and learning \\
\hline $\mathrm{X} 8$ & Teach clearly so as to make himself understood and write neatly on the blackboard \\
\hline X9 & Obey the language norms, speak smoothly and accurately \\
\hline $\mathrm{X} 10$ & Be careful and patient in treatment of questions raised by students in and out of class \\
\hline $\mathrm{X} 11$ & Teaching is enlightening so as to promote students to take the initiative to think \\
\hline $\mathrm{X} 12$ & Lectures are systematic and illustrate the links among chapters \\
\hline $\mathrm{X} 13$ & Be able to use a variety of teaching aids actively and effectively \\
\hline $\mathrm{X} 14$ & Good at adjusting the classroom atmosphere, never be too relaxed or too serious. \\
\hline $\mathrm{X} 15$ & Encourage students to participate in class discussions \\
\hline $\mathrm{X} 16$ & Be able to make full use of class time effectively \\
\hline $\mathrm{X} 17$ & Test proposition could reflect the focus of teaching content \\
\hline $\mathrm{X} 18$ & Lecture progress is conducive to the promotion of course learning \\
\hline X19 & Teaching content could highlight the key points \\
\hline $\mathrm{X} 20$ & Classroom teaching effect is good so that students can master the knowledge well \\
\hline
\end{tabular}

Establishment of Multiple Linear Regression Model. Multiple linear regression analysis is to study a dependent variable and a number of independent variables of the linear relationship. The dependent variable (denoted by $\mathrm{Y}$ ) is the teaching effect of English teachers (ie, $\mathrm{x} 20$ ). The independent variables are 19 indicators (ie, x1-x19) of English teachers' teaching attitude, teaching content, teaching methods and teaching organization. Multivariate Linear Regression Model with Dummy Variables is: $\mathrm{Y}=\mathrm{b} 0+\mathrm{b} 1 \times 1+\mathrm{b} 2 \times 2+\mathrm{b} 3 \times 3+\mathrm{b} 4 \times 4+\mathrm{b} 5 \times 5+\mathrm{b} 6 \times 6+\mathrm{b} 7 \times 7+\mathrm{b} 8 \times 8+\mathrm{b} 9 \times 9+\ldots+\mathrm{b} 19 \times 19$. In the study, we can not confirm that there is a linear relationship between the dependent variable $\mathrm{Y}$ and the independent variable $\mathrm{x} 1-\mathrm{x} 19$.

After the regression model was established, the stepwise regression analysis was adopted to eliminate the factors that had no significant effect on the teaching effect. The residual variables were used to establish the regression equation, and then the test was conducted again. Finally, the regression equation was obtained $Y=-01162+01346 \times 2+01246 \times 18+01197 \times 19+01150 \times 15+01100 \times 8$ 
Table 2. Variance analysis

\begin{tabular}{|c|c|c|c|c|c|}
\hline & $\begin{array}{c}\text { Degree of } \\
\text { freedom }\end{array}$ & $\begin{array}{c}\text { Sum of } \\
\text { squares }\end{array}$ & Mean squares & F-value & $\begin{array}{c}\text { Significance } \\
\text { level }\end{array}$ \\
\hline $\begin{array}{c}\text { Regression } \\
\text { analysis }\end{array}$ & 5 & 30.449 & 6.090 & 633.596 & 0.000 \\
\hline Residuals & 196 & 1.884 & 0.010 & & \\
\hline Sum & 201 & 32.333 & & & \\
\hline
\end{tabular}

Table 3. t-test for regression coefficients

\begin{tabular}{|c|c|c|c|c|c|}
\hline $\begin{array}{c}\text { Factors affecting } \\
\text { teaching } \\
\text { effectiveness }\end{array}$ & bi & beta & t-value & $\begin{array}{c}\text { Significance } \\
\text { level }\end{array}$ & $\begin{array}{c}\text { Order of } \\
\text { effectiveness }\end{array}$ \\
\hline & $\mathrm{b} 0=-0.162$ & & -1.908 & 0.058 & \\
\hline $\mathrm{X} 2$ & $\mathrm{~b} 2=0.346$ & 0.321 & 7.885 & $0.000^{* *}$ & 1 \\
\hline $\mathrm{X} 18$ & $\mathrm{~b} 18=0.246$ & 0.245 & 3.572 & $0.000^{* *}$ & 2 \\
\hline $\mathrm{X} 19$ & $\mathrm{~b} 19=0.197$ & 0.197 & 3.924 & $0.000^{* *}$ & 3 \\
\hline $\mathrm{X} 15$ & $\mathrm{~b} 15=0.150$ & 0.155 & 2.915 & $0.004^{* *}$ & 4 \\
\hline $\mathrm{X} 8$ & $\mathrm{~b} 8=0.100$ & 0.096 & 2.037 & $0.043^{*}$ & 5 \\
\hline
\end{tabular}

Conclusion of Regression Analysis and the Analysis of Factors Affecting the Teaching Quality. According to the multiple linear regression analysis and obtained regression equation: $\mathrm{Y}=$ $-01162+01346 \times 2+01246 \times 18+01197 \times 19+01150 \times 15+01100 \times 8$, it can be concluded that among the 19 dummy variables introduced, $\mathrm{x} 2$ (English teachers' work enthusiasm, coefficient is 0.321 ), $\mathrm{x} 18$ (English teachers teaching progress, coefficient 0.245), x19 (English teachers teaching content depth, coefficient 0.197), x15 (English teachers to encourage students to participate in classroom discussions, coefficient 0.155), x8 (English teachers clearly understand the teaching, coefficient 0.096). The above five factors have significant impacts on the teaching effectiveness of English teachers, in another word, the strong linear relationship. while the other 14 factors have no significant effects on the teaching of English teachers. In the analysis of five factors that are mostly correlated with teaching effectiveness, the one that ranked first is x2 (English teachers work enthusiasm, belonging to category of the English teachers teaching attitude. That is to say, English teachers' teaching attitude has the greatest contribution to the teaching effectiveness(the regression coefficient is 0.321 ), which is much higher than other factors in influencing the teaching effect of English teachers.

\section{The Impact of English Reform}

After the reform of the college entrance examination, the impact of the students in English is obtained mainly through classroom observation and interviews with the channels. This situation is common, which often leads to the biased understanding of the most important part of a foreign language, since focusing on improving the utility of the examination techniques makes most students lost the ability to improve the application capability of the language by drowning in a lot of questions. ",Analysis of Questionnaire Survey.

Part I: Basic information research 
1. Gender Distribution of Respondents in Questionnaires Survey

\begin{tabular}{|l|c|c|}
\hline \multicolumn{1}{|c|}{ Options } & Sum & Proportion \\
\hline male & 131 & $56.22 \%$ \\
\hline female & 102 & \\
\hline Number of people participating in the survey & $\mathbf{2 3 3}$ & \\
\hline
\end{tabular}

2. Grade Distribution of Respondents in Questionnaire survey

\begin{tabular}{|c|c|c|}
\hline Options & Sum & Proportion \\
\hline Grade eleven & 47 & $20.17 \%$ \\
\hline Grade twelve & 172 & $\begin{array}{ll} & 73.82 \%\end{array}$ \\
\hline Grade ten & 6 & I $2.58 \%$ \\
\hline Return students & 8 & 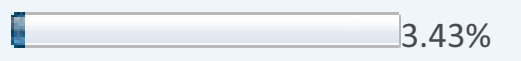 \\
\hline Number of people participating in the survey & 233 & \\
\hline
\end{tabular}

Part II: The Investigation of the Impact of College English Examination

1. Whether the impact on the college entrance examination is clear (average point is 3.46)

\begin{tabular}{|l|c|c|c|}
\hline \multicolumn{1}{|c|}{ Options } & Sum & Proportion \\
\hline Very clear & 6 & 8 & $3.5 \%$ \\
\hline Clear & 107 & & $45.92 \%$ \\
\hline unclear & 97 & & $41.63 \%$ \\
\hline very unclear & 15 & & $6.44 \%$ \\
\hline too unclear & 233 & \\
\hline Number of people participating in the survey & & \\
\hline
\end{tabular}

2. Whether they are satisfied with the English language reform (average score: 3.45)

\begin{tabular}{|l|c|l|l|}
\hline \multicolumn{1}{|c|}{ Options } & Sum & \multicolumn{2}{c|}{ Proportion } \\
\hline Very satisfied & 5 & 12 & $5.15 \%$ \\
\hline Satisfied & 105 & & $45.06 \%$ \\
\hline Just so-so & 94 & & $40.34 \%$ \\
\hline Unsatisfied & & \\
\hline
\end{tabular}




\begin{tabular}{|l|c|l|}
\hline Very unsatisfied & 17 & - \\
\hline Number of people participating in the survey & $\mathbf{2 3 3}$ & \\
\hline
\end{tabular}

The Impact of the Reform of the College Entrance Examination on English Teachers. To fully understand the role that the reform of the college entrance examination plays on the English teaching in high school, we need to know about English teachers' thinking. The above reflects that, on the one hand, the purpose of education is not clear, on the other hand, it also reminded the that school should provide more training opportunities for teachers. According to the interview, the results are shown as follow:

The reform of the college entrance examination has the greatest impact on English teaching content in high school, followed by teaching time arrangements, the teaching method has the least impact. The affected teaching content is mainly because that English teachers would automatically increase the content not involved in the textbooks but appeared in the college entrance examination. "Part of the English teachers stressed that they did not change the teaching methods, but they change the direction of teaching and expand the scope of knowledge according to the college entrance examination trends.

\section{The Strategy of Utilizing the Positive Impact of the English College Examination on English Teaching}

School. The senior middle schools should perfect the English curriculum as much as possible, pay ing attention to cultivating students' English listening, speaking, reading and writing ability, so that students can really cultivate the ability of learning the western culture and application of the language. At the same time arrangements should also be scientific, training objectives should be diversified, the focus should be different. English teachers should make reasonable teaching plans with in the limited class hours to, taking into account the students all-round development of language skills as far as possible.

English teacher. Here are some suggestions for teachers:As an English teacher, they should be more serious in the treatment of second language acquisition and the understanding of second language education and take into account the objectives of English subjects and college entrance examination English test standards. Besides, they should try to avoid only focus on improving students' performances in the college entrance examination English achievement rather than the ability of language communication.

Students. Here are some suggestions for students:To understand the essence of college entrance examination and clear their learning objectives. English learning is the essence of language learning, the most direct purpose is to learn to use information exchange and language interaction. The college entrance examination, as the most important selection examination, has been given more meanings by society, it has significant impact on anyone's further study chasing or future employment.

\section{References}

[1] Liu Haifeng.Chinese Examination Development History [M]. Wuhan: Central China Normal University Press, 2002,335.

[2] Ding Dingfang. Foreign language teaching reform: Problems and Countermeasures [M]. Shanghai: Shanghai Foreign Language Education Press.

[3] Zhong Qiquan. Ordinary high school new curriculum program guide [M]. Shanghai: East China Normal University Press, 2003,60. 
[4] Yang Xuewei. China examination reform [M]. Tianjin: Tianjin University Press, 2001,99.

[5] Shi Zhongying. Knowledge transformation and educational reform [M]. Tianjin: Educational Science Press, 2001,82.

[6] GE Dahui.Admission examination problems and countermeasures: an analysis of "examination-oriented education" [M]. Shanghai: East China Normal University Press, 2001,13.

[7] Tian Shengli. China College Entrance Examination Yearbook [M]. Tianjin: China Encyclopedia Publishing House. 